\title{
China Analysis Rationalizing administrative division: the resistance of the prefecture
}

\section{Thibaud Voïta}

\section{(2) OpenEdition \\ 12 Journals}

Electronic version

URL: http://journals.openedition.org/chinaperspectives/2323

DOI: 10.4000/chinaperspectives.2323

ISSN: 1996-4617

Publisher

Centre d'étude français sur la Chine contemporaine

\section{Printed version}

Date of publication: 15 September 2007

ISSN: 2070-3449

\section{Electronic reference}

Thibaud Voïta, " China Analysis Rationalizing administrative division: the resistance of the prefecture », China Perspectives [Online], 2007/3 | 2007, Online since 09 April 2008, connection on 15 September 2020. URL : http://journals.openedition.org/chinaperspectives/2323 


\title{
Rationalizing administrative division: the resistance of the prefecture
}

\author{
Compiled and commented by Thibaud Voïta based on: \\ - Wang Hongru et al. "The 'Provinces Govern the Counties': A New Division of Rights at the Local Level"; Xu Antuo, \\ "The management of the county by the province is a necessity of the market economy," Zhongguo Jingii Zhoukan, \\ 11 June 2007, 22nd week ${ }^{(5)}$
}

A ccording to Article 30 of the Constitution of the People's Republic of China, the country is divided into three levels of territorial administration:

- The provinces, 省 (as well as the autonomous regions and special municipalities 自治區、直轄市).

- The counties, 縣 (as well as the autonomous counties, the autonomous regions, the cities, 自治縣、自治州、 縣 市).

- The townships, 鄉 (as well as the nationality townships and the towns, 民族鄉鎮).

To this division, administrative practice has added a fourth level between the counties and the province: the prefecture (市). ${ }^{(6)}$ The latter initially managed the county. This level acquired great importance during the period of state planning; facilitating tax levies intended for the central government and guaranteeing the application, at the county level, of Beijing's economic directives and policies. What is more, the administrative functions given to the prefecture have increased the town's economic influence, regional development and political stability.

However, this administrative level has now become unnecessary. Xu Antuo associates numerous shortcomings with this system. Its presence leads to a compartmentalisation of the territory and administrative redundancies that have harmful consequences at the lower administrative levels. The prefecture has become synonymous with administrative costs and complexity. It handicaps innovation and development at the administrative level below it while increasing the opportunities for corruption and embezzlement. Finally, the existence of the prefecture as an administrative echelon is said to increase disparities. In his article, $\mathrm{Xu}$ adopts a liberal point of view, demanding a lightening of the local administrative apparatus in order to liberate the energies and the capabilities of the different localities.

The tax reforms of the 1990s were a first step towards weakening the prefectures: they consisted in a downward redistribution (下放) of certain financial responsibilities from the province to the prefecture, namely: the transfer of payments, budgetary implementation, fund distribution, debt management, etc.

The shift from the "management of the counties by the prefecture" (市管縣) to the "management of the counties by the province” (省管縣) should allow this process to go even further. It consists in an initial phase of two major transfers from the prefecture to the province: 1) the transfer of financial responsibilities; and 2) the transfer of purely administrative management processes (human resources, evaluation of cadres, etc.). This project can be found in the Eleventh Five-Year Plan. The authorities expect this reform to play a part in resolving the problem of the sannong (三蕽) ${ }^{(7)}$ by rationalising the tax burden that weighs heavily on the peasantry. The spirit and the motivation that presided at the establishment of this measure were summarised by Wen Jiabao in June 2005 during a meeting of the working group on the national reform of peasant taxation: "it is necessary to reform the public finance management model, adapt to local conditions; then we can test out the reform of the management of the counties by the provinces."

The province of Zhejiang played a pioneering role when it began to try out this reform in 13 counties in 1992. Zhejiang's success allowed these measures to be disseminated.

5. It is to be noted that Xu Antuo is a high-ranking official at the Chinese Ministry of Finance. The other article was apparently written in close collaboration with colleagues of Xu and researchers at the Chinese Academy of Social Sciences. Consequently, the opinions presented here are primarily those of the Ministry of Finance. We do not have any information on the views of the local authorities or of the National Development and Reform Commission (NDRC).

6. This denomination is complex: thus, the character 市 is used to designate the prefectures but also the cities (at the administrative level of the county). The same character can be found in 直轄市, which serves to designate the special municipalities of provincial rank.

7. The sannong or three agricultural problems concern the peasants, the township and agriculture. According to the official discourse, solving these problems should allow the ills of China's rural world to be put right. 
Today, 16 provinces and the four special municipalities have tried them out (cf. box). At present, this reform is said to be in application in two-thirds of the territory. It should also be noted that in the autonomous provinces (only Xinjiang, Inner Mongolia and Ningxia are cited in the article), this type of measure is in conflict with the law on the autonomy of the regions populated by ethnic minorities. That is also the case in certain counties, such as Sichuan for example. This explains why those provinces cannot apply the reform.

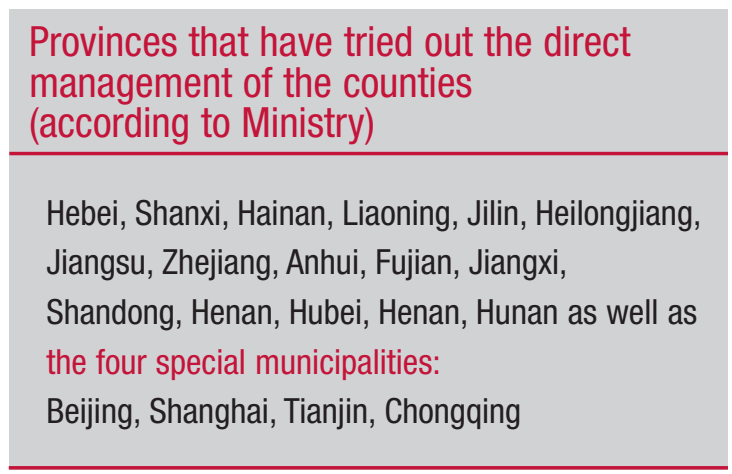

However, the measures that have been adopted are insufficient for fixing the above-mentioned problems. The reform has in fact not been applied uniformly across the whole territory. Bureaucratic habits are the main obstacle: the administrations at prefecture level refuse to give up their former functions. Only the province of Zhejiang has applied the measures to the point that the prefectures no longer take care of the entire management of the counties. Anhui has similarly reached a fairly advanced stage, as it manages the public finances of its counties. In contrast, in certain provinces (not quoted in the article), the reforms only exist on paper, in particular in the matter of the transfers of payments.

The administrative authorities higher up in the hierarchy have been nicknamed the "mothers-in-law" (婆婆), so the counties have to support two mothers-in-law, a problem that is known as the "problem of the two mothers-in-law" (雨個 “婆婆” 的問題 prefecture and province). This situation is untenable in the long term.

Furthermore, this reform may create new problems. First of all, the provinces will have to manage numerous counties. It is possible that, as a consequence, they will have to review the functioning of their own administrations. A reform is being studied. What is more, the duties of the departments of the province are not always clear. New overlaps of responsibilities can well be expected generating new dead weights in the administration of the province. Another risk is that the elimination of the management by the prefecture will bring with it a rise in inequalities. It will be difficult to gain momentum for these reforms in the most remote regions: it is a reform of the whole administrative system (系統) that is at stake. Finally, effective controls over the counties by the province will have to be put in place. $\bullet$ 